\title{
PSYCHE
}

VOL. XXXIII.

FEBRUARY 1926

No. 1

\section{NOTES ON THE ODORS OF SOME NEW ENGLAND BUTTERFLIES.}

\author{
Austin H. Clatrk.
}

Smithsonian Institution, Washington, D. C.

Considering the strength of the odors exhaled by one or both sexes of many of our common butterflies it is quite extraordinary that they have received so little attention.

The following notes were made chiefly at Manchester and Essex, Massachusetts. It is quite possible that in certain species there will be found to be a geographical variation in the strength or type of the odor which may or may not be correlated with variation in color or in other characters. It is also quite possible that further investigation will show in certain types more or less dimorphism in the odors such as has been reported in the southern Papilio polydamus.

The noses of my two young sons being much more acute than mine, their assistance in experimenting with some scores of captured butterflies was of the greatest value; in fact some of the odors readily detected by both of them I was unable to perceive at all. Ordinarily the testing of butterflies for odors is an interesting and pleasant task; but one must always be prepared for most unwelcome surprises as in the case of the females of the fritillaries.

Close observation of the courting of the argynnids and of Eurymus philodice has led me to believe that the male odors are sexual stimulants pure and simple, while the female odors, always disagreeable in varying degrees and sometimes nauseating, are protective. 
Speyeria idalia (Drury).- - The odor of the male is uniformly strong and resembles that of the males of Argynnis cybele and $\boldsymbol{A}$. aphrodite, but is sweeter and more flowery. Mr. Scudder compared it to musk, but it is to me more flowery than musk.

Argynnis cybele (Fabricius).-The males have a faint to strong spicy odor resembling sweet flag or sandal-wood which can always be detected and is sometimes strong enough to be evident when the insect is fluttering in the net. It is strong in one individual out of every four or five and is often exceptionally strong in very worn examples. Very fresh insects appear always to be nearly, sometimes indeed quite, odorless. It appears to take some time after the wings are fully formed and functional for the odoriferous secretion to become diffused sufficiently to give the characteristic fragrance.

Mr. Scudder specifically stated that both this species and the following are scentless. It is probable that he examined only individuals too recently emerged for the scent to have become effectively distributed.

In the females the wings are odorless, but the pair of short blunt stout soft orange appendages which on pressing the abdomen are extruded from between the last two segments dorsally gives off a powerful nauseating odor recalling that of the osmateria of the caterpillars of Papilio polyxenes.

The females of our fritillaries are larger and more conspicuous than the males and at the same time less shy with a less swift and less erratic flight. They also appear to be much longer lived, for by the end of August all the still fairly numerous individuals remaining are females busily engaged in searching out their food plants and seldom seen on flowers. It is a reasonable inference that in these butterflies both sexes are protected to an appreciable extent by the formidable abdominal glands of the females.

Argynnis aphrodite (Fabricius).--The odors of both sexes of this butterfly as found in this region exactly resemble those of the corresponding sexes of A.cybele.

Brenthis montinus Scudder.-Professor John H. Gerould writes me that he has noticed an odor in this species similar to 
that in the two preceding. I have made no personal observations on it.

Brenthis myrina (Cramer).-No odor was detected in either sex; but the females have the same odoriferous organs as are found in the females of related types which undoubtedly are the same in function.

Junonia cœenia Hübner.-In the large and handsome dark variety with the under surface of the wings dull pinkish red which is the commonest about Washington in the fields where the food plant (Agalinis purpurea) is abundant the males have a rather strong sweet odor which is sometimes evanescent. This variety has curiously soft wings and always feels as if recently emerged. It is sluggish, and rarely flies for more than fifty feet or so.

The variety occurring in New England is much smaller, distinctly brown above and buffy gray below. The wings are hard and brittle and most individuals caught are damaged in contrast to the other form in which broken specimens are relatively rare. It is exceedingly alert and active, a much stronger flier than the other, less easily visible on the wing and much more difficult to eatch. Specimens from Washington are indistinguishable from those from Massachusetts. The males, so far as I can find, are scentless; at any rate the odor is much less pronounced than in the other type.

About Washington the small light active form is found sparingly with the other, from which it differs in keeping mostly well above the ground resting on the tops of the higher plants and quickly darting off on the slightest provocation. It is much more frequently to be seen on barren hillsides, about the city parks and streets, and generally in unfavorable localities where the other is not found.

One might reasonably infer that this well marked variety is a special form particularly fitted for long continued flight and therefore especially adapted for distributing the species.

Vanessa cardui in New England also appears to have a special form distinctively colored on the under side with corresponding habits. This form flies in a straight line usually 
from ten to fifteen feet above the ground keeping on till it is out of sight in contrast to the usual type which in its habits is much like $V$. huntera.

In Feniseca tarquinius it would seem that certain individuals are specialized as migrants. These fly slowly in a straight line across the fields usually a foot or so above the grass tops for long distances; in fact I have never seen them rest. Typically this insect's flight is most erratic suggesting a small and very active satyrid, with frequent rests.

Basilarchia archippus (Cramer).-Both the boys reported in this species a pronounced and disagreeable odor which the younger compared with that of Anosia plexippus females. It is not a little curious that this butterfly should both look and smell like this larger form. But the flight of the two is different and one can easily tell them on the wing at any distance.

Anosia plexippus (Linne).-The females have a rather strong and disagreeable odor resembling that of cockroaches or of carrots. The males have the same odor, but in them it is very faint and is overlaid with a faint very sweet odor like that of milkweed or red clover flowers.

Eurymus philodice (Godart).-The males have a distinct and uniformly strong odor resembling that of sweet grass or sweet hay. The females seem to be odorless.

Eurema euterpe (Ménétries).-The males, in spite of their diminutive size, have a pronounced fragrance similar to that of the males of the preceding species but sweeter and more flowery.

Papilio polyxenes Linné.-The males have a faint sweet odor resembling that of carrot flowers which is very pleasant. Apparently an identical odor is found in the males of the European $P$. machaon.

Two males examined in Washington had a strong sweet flowery odor of the same type.

Papilio glaucus Linné.-The males all have a sweet flowery odor varying from faint to fairly strong which resembles that of the males of $P$. troilus though it is never so pronounced. The females have a disagreeable odor pungent in quality resembling rubber cement or creosote which is very strong in some and ap- 
parently stronger in the females taken about Washington than in those taken in New England. The same odor can sometimes be detected in the males, though very faintly.

Papilio troilus Linné.-The males have a distinct and rather strong sweetish odor difficult to describe but exactly resembling that of Nabisco or Huntley and Palmer's honey biscuits.

Laërtias philenor (Linné).-From observations made in Washington it was found that the males have a sweet flowery odor similar to that of the males of Papilio polyxenes though not so strong. The females have a strong pungent and disagreeable odor.

Mr. W. H. Edwards reported a disagreeable odor in this species but did not give the sex of the individual examined. Mr. Scudder very carefully investigated a specimen fresh from the chrysalis and found no odor. Mr. Edward's example undoubtedly was a female. Mr. Scudder's, which was a male, was probably too fresh for the odor to have become detectable. 

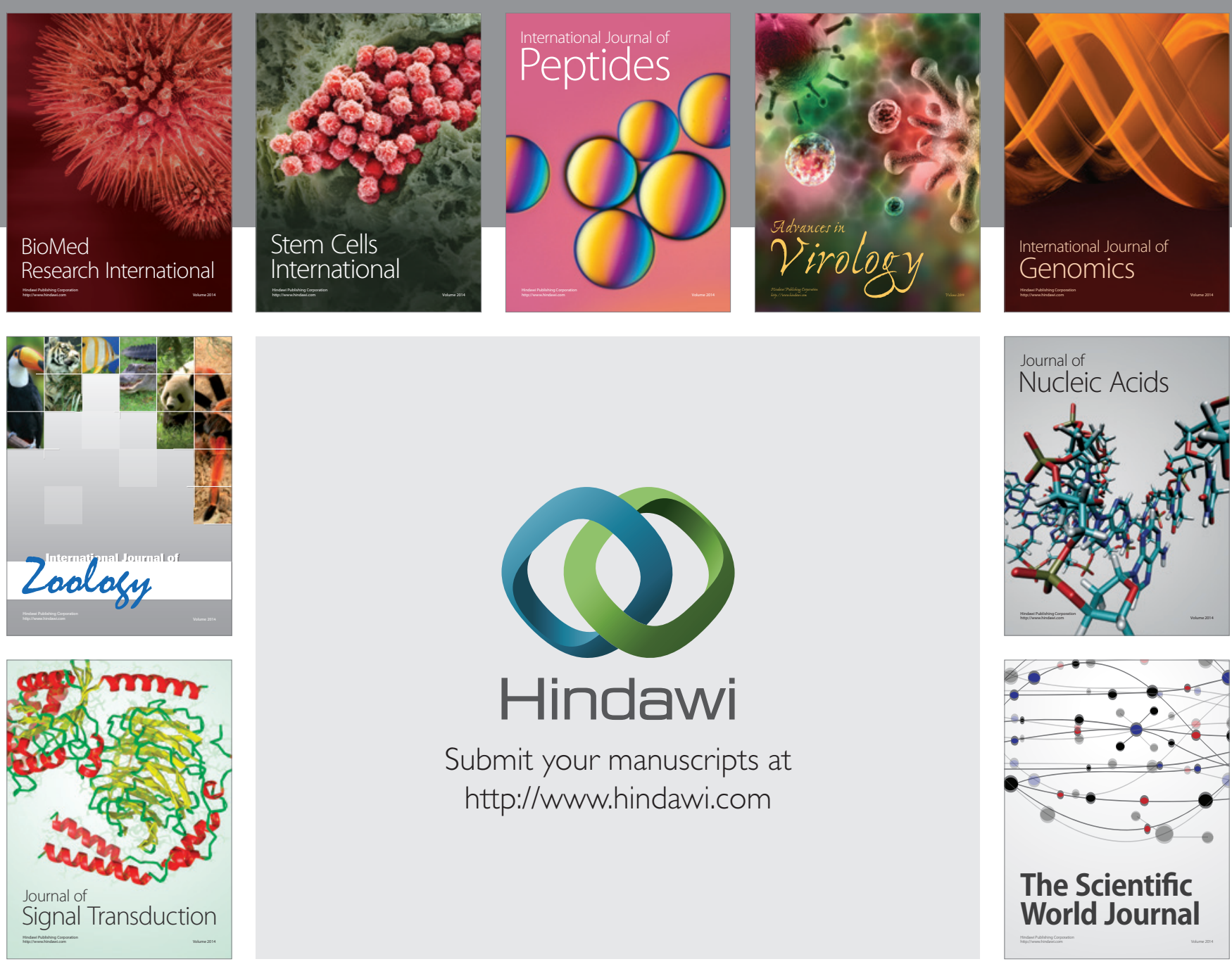

Submit your manuscripts at

http://www.hindawi.com
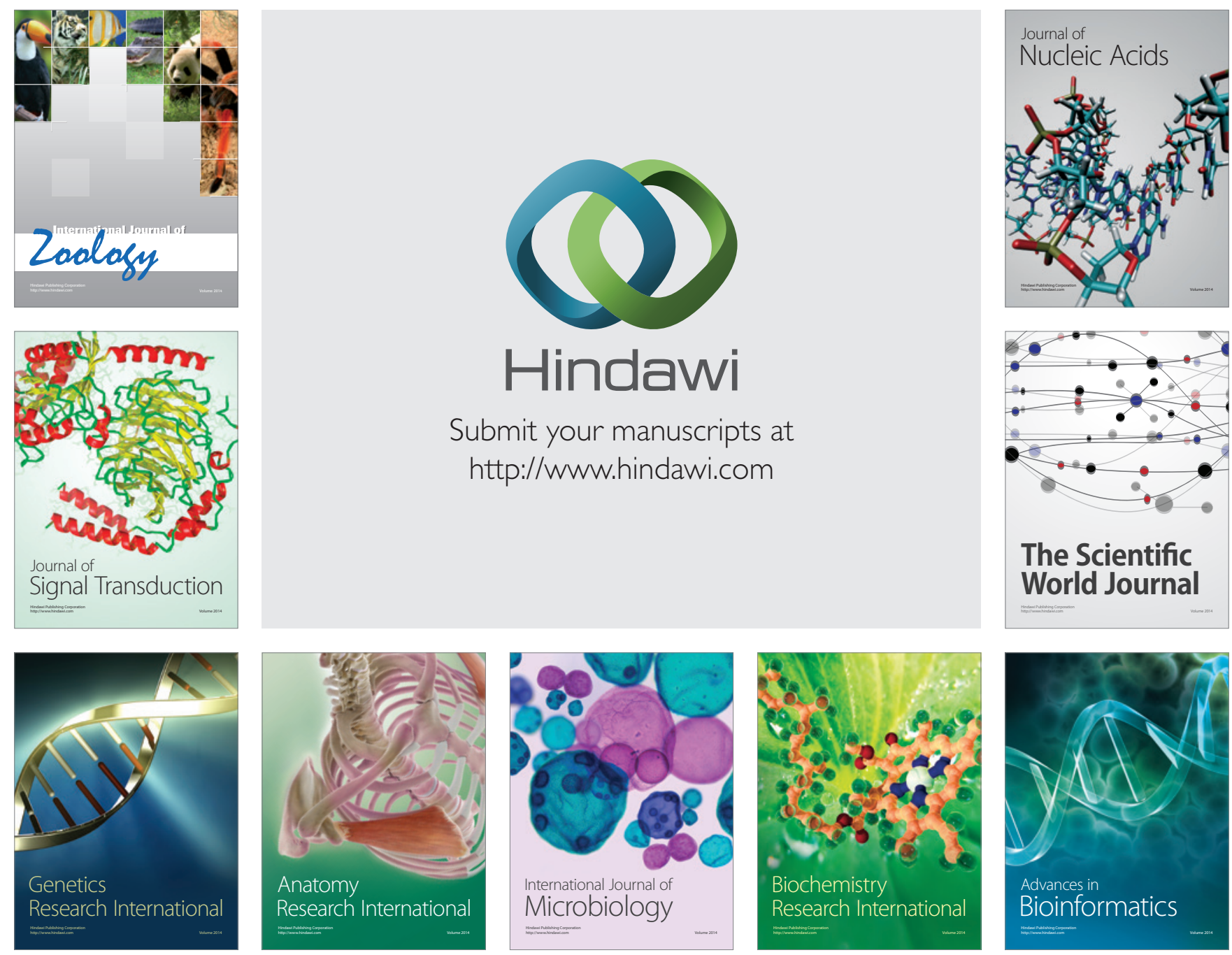

The Scientific World Journal
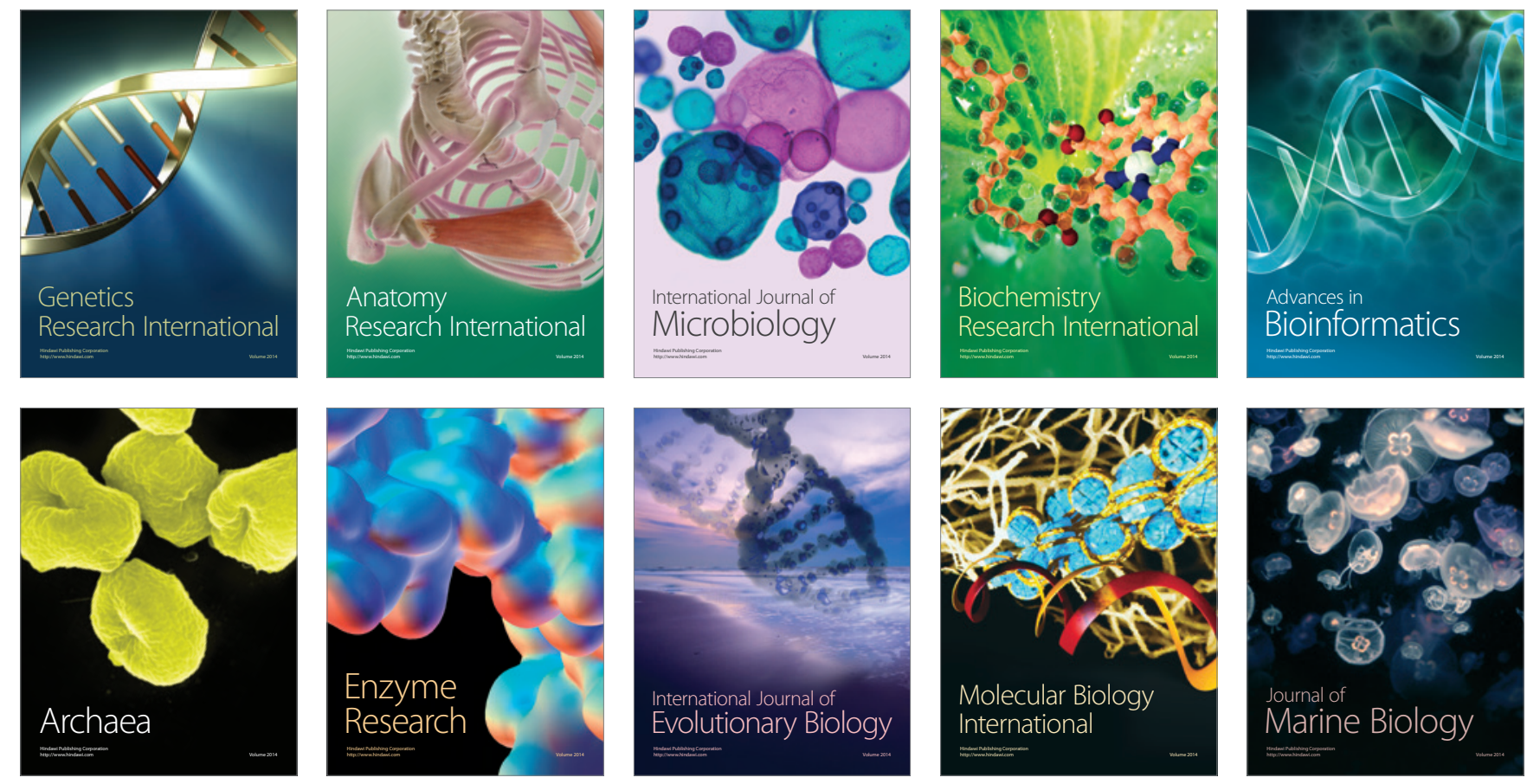